\title{
DIVIDEND POLICY AND ECONOMIC VARIABLE TO STOCK PRICE VOLATILITY: COMPARISON OF INDONESIA AND MALAYSIA
}

\author{
Vega Rut Harlina ${ }^{\bowtie}$, Moh. Khoiruddin
}

Management Department, Faculty of Economics, Universitas Negeri Semarang, Semarang, Indonesia

\section{Info Article}

\section{History Article:}

Received September 2018

Approved September 2018

Published December 2018

Keywords:

Macro and Micro Variable; Stock Price Volatility.

\begin{abstract}
This research aims to examine the effect of dividend policy, micro variables, and macroeconomic on stock price volatility. The population in this research are companies in the financial sector listed at Indonesia Stock Exchange and Malaysia Stock Exchange in 2016-2017. A number of samples that used is 58 companies for Indonesia and 28 companies for Malaysia with purposive sampling method. Dividend policy is proxied by EPS, the micro variable is proxied by GA and $\mathrm{EV}$, and the macro variable is proxied by exchange rates and interest rates. The analytical method used is CEM and REM with programs Eviews 9. This research concludes that in Indonesia EPS, exchange rates and interest rates have an effect on SPV. While in Malaysia, only EPS and exchange rates have an effect on SPV.

Abstrak

Penelitian ini bertujuan untuk menguji pengaruh kebijakan dividen, variabel mikro, dan makro ekonomi terhadap volatilitas harga saham. Populasi dalam penelitian ini adalah perusahaan sektor keuangan yang terdaftar di Bursa Efek Indonesia dan Bursa Efek Malaysia pada tahun 2016-2017. Jumlah sampel yang digunakan adalah 58 perusahaan untuk Negara Indonesia dan 28 perusahaan untuk Negara Malaysia dengan metode purposive sampling. Variabel kebijakan dividen diproksikan oleh $E P S$, variabel mikro diproksikan oleh $G A$ dan $E V$, dan variabel makro diproksikan oleh nilai tukar dan suku bunga. Metode analisis yang digunakan adalah CEM dan REM dengan program Eviews 9. Hasil penelitian ini menyimpulkan bahwa di Negara Indonesia EPS, nilai tukar, dan suku bunga berpengaruh terhadap SPV. Sedangkan, di Negara Malaysia hanya EPS dan nilai tukar yang berpengaruh terhadap SPV.
\end{abstract}




\section{INTRODUCTION}

Now, developments in the business world are increasing rapidly. Companies are required to operate well and generate optimal operating profit. Companies that can generate their own capital, make investments, base capital, or capital loans. According to Ramadan (2013) dividends are more than just instruments for a net of costs, a significant amount in the distribution level may have an impact on growth, namely achieving dividend policy.

Dividend policy is an action program that is used by companies to decide how much residual profit must be paid to shareholders in dividends (Ilaboya \& Aggreh, 2013). Dividends are company profits given to shareholders according to to the size of share ownership in the company. Retained earnings are part of the company's net income held by the company and not paid as dividends to shareholders (Tastaftiani \& Khoiruddin, 2015). The company uses the retained earnings for investment projects because of the company's monetary interests. But, according to Nazir et al. (2012) the company's maximum income must be paid as dividends rather than retained earnings so as not to be invested in a less profitable project.

Decisions of capital budgeting or investment decisions are decisions to invest in tangible and intangible assets (Cahyaningdyah \& Ressany, 2012). Every market participant, both trader, an the investor is always faced with market risk for the possibility of obtaining capital gains or capital losses, given that high-risk, high returns, lowrisk low returns (Setiawan \& Wijayanto, 2017). Investors naturally avoid risks and the volatility of investments they hold is important for them because as a measure of the level of risk faced (Hussainey et al., 2011). In an efficient market condition stock prices in the market have reflected all the information on the market. According to Adhita and Agustin (2013), investors reaction which is reflected in the stock price will be faster and reactive if the market conditions are said to be efficient.

According to Nazir et al. (2010) companies that have fewer growth opportunities will face more stock price volatility than companies that have many opportunities to grow. Investors with risk-taking tendencies prefer this high volatility condition because it allows them to obtain higher returns (Sutrisno, 2017). Growth in assets is important because it reflects the development of companies that are needed by investors. The growth of assets itself provides an overview of the guarantee of the ability of the company to pay off its liabilities if it is in debt using debt (Puspida \& Budiyanto, 2013). Earnings volatility shows the level of fluctuations in profits obtained by banks from their operational activities over several periods (Wijayanti \& Diyanti, 2017). The exchange rate is the price of the domestic currency against another country's currency. The interest rate is one of the things that become an investment consideration to make decisions in investing. (Prasetyo \& Darmawan, 2017). When interest rates rise many investors sell their shares and invest their funds in deposits because they have a lower risk. Conversely, when interest rates decrease many investors invest their funds in the capital market.

The capital market in Indonesia is currently smaller and less liquid than other ASEAN countries. Knowledge about the financial condition of Indonesian people is low, but since 2016 the JCI has increased by $19.99 \%$. The increase in the financial sector contributed more to an increase of $40.52 \%$. From these conditions researchers compared with Malaysia. Malaysia is a neighboring country that is still in one scope, namely ASEAN. Malaysia is a developing country that has conditions similar to Indonesia.

Research by Shah and Noreen (2016) testing between dividend policy and stock price volatility in companies in Pakistan. The results show that growth in assets, earnings volatility and earnings per share have a positive effect on stock price volatility. According to Asghar et al. (2011) earnings volatility, dan growth in asset has a negative correlation with stock price volatility. It's the difference with Ramdhani (2012) earnings volatility has a positive effect on stock price volatility. Adjasi (2009) state that exchange rates and interest rates have a positive effect on stock price volatility. Exchange rates and interest rates have no effect on stock price volatility (Azura et al., 2018). This study aims to examine whether there are effects of earnings per share, growth in assets, earnings volatility, exchange rates and interest rates on stock price volatility.

Signaling theory teaches that every action contains information (Atmaja, 2008). Every information announced by the company is seen as a signal for future investors in making decisions. Information that comes from within the company is in the form of financial statements. Many companies fail to provide financial reports or financial information in accordance with the standards required by financial institutions (Yanto et al., 2017). In a perfect capital market according to Miller and Modigliani (1961), all traders have access to the same information and prices and 
no fees to know about the prevailing prices and about all other relevant stock characteristics. This theory is used because it underlies the behavior of investors who need all the information about the company for their investment needs. Stock investors are shareholders who are issued by a company, which also has ownership rights to the company so that investors are entitled to all information related to the development of the company (Khoiruddin \& Faizati, 2014). Payment of dividends will be considered as a signal or merely an agency conflict (Prasetyo, 2013).

Investment is a commitment to a number of funds or other resources carried out at this time, with the aim of obtaining a number of profits in the future (Tandelilin, 2010). Investment is simply defined as an effort to obtain results or profits (Nofiatin, 2013). It can be concluded that investment is channeling a number of funds today in the hope of obtaining profits in the future. Investors, creditors and users of financial statements need relevant information regarding a company's financial statements for decision making (Yendrawati \& Pratiwi, 2015).

The capital market is an activity concerned with public offerings and securities trading, public companies relating to the securities issued, as well as institutions and professions related to securities. A capital market is a meeting place between those who need funds and those who have excess funds by trading securities, such as stocks and bonds. The capital market is a means for business funding or as a means for companies to get funds from investors or investors (Asih \& Akbar, 2017). The capital market provides convenience in obtaining funds for those who need funds (debtors).

Stock price volatility is a change in the rise and fall of stock prices over a certain period. One analytical tool in assessing stock prices is through the company's fundamental analysis through analysis of its financial ratios (Safitri, 2013). A stock buyer wants a low stock price and experiences an increase after the purchase. Conversely, sellers want a high stock price when selling. Micro factors that influence stock price volatility, namely dividend policy (dividend payout ratio, earnings per share and dividend yield), trading frequency, trade size, trading volume, earnings volatility, growth in Asset, firm size, return on equity and leverage. Macro factors that influence stock price volatility are inflation, interest rates, exchange rates, productivity levels and market values. According to Tandelilin (2010) the greater of the volatility, the greater of the probability that the stock price will experience the desired change.
Dividend policy is a decision to provide profits in the form of dividends to shareholders or retained earnings for financing in the future. A profitable company and to increase the likelihood that the investment will pay dividends, so the company that pays dividends can choose funding sources that come from profits or from debt (Yulianto et al., 2015). Dividend policy determines how much profit shareholders will get (Sari, 2013). Cash dividends paid are considered by investors as a signal of the company's future prospects (Sari \& Wijayanto, 2015). Brealey et al. (2015) stated that dividend decisions were not a problem in the perfect financial market. According to Adesola and Okwong (2009), the magnitude of the impact of earnings or earnings per share on stock market prices greater than dividend payments shows that the main determinant of the value of a market share for companies in Nigeria is no longer dividends but earnings per share. Growth in assets is the ratio of growth in Asset rates from year to year.

According to Indriani and Widyarti (2013) growth in Asset is a change in company assets measured by the ratio between the total assets of the current period (asset s $_{s}$ minus the total assets of the previous period (asset ${ }_{t-1}$ ), to the total assets of the previous period ( asset $_{t-1}$ ). Total growth in Asset is very influential in determining dividend policy because the greater the growth of company assets, the company will prefer to use the profits obtained to finance the expansion rather than use it to pay dividends (Lestari \& Sulistyawati, 2017). Earnings volatility is the rate of change in earnings compared to total assets. The existence of earnings growth that continues to increase from year to year will provide a positive signal regarding the company's performance (Hartini, 2012). Earnings volatility is calculated as the ratio of operating profit to total assets (Asghar et al., 2011).

The exchange rate is the price of a specific currency against the currency of another country. The exchange rate is the amount of money needed, namely the amount of Rupiah needed to obtain one unit of foreign currency (Listriono $\&$ Nuraina, 2015). If a country's currency is expected to strengthen, foreign investors may be willing to invest in the country's securities to benefit from the currency's movements (Madura, 2008). The exchange rate reflects the value and trust of a country's currency against other countries (Ardhi et al., 2017). The exchange rate that occurs in the market is determined by the demand and supply for the currency. According to Bank Indonesia's definition, the BI Rate is a policy interest rate 
that reflects the monetary policy stance or stance set by Bank Indonesia and announced to the public. Interest rates in return for a number of investments given to investors. When interest rates rise many investors sell their shares and invest their funds in deposits because they have a lower risk. Changes in interest rates affect relative investment in foreign securities, which affect the demand and supply of currencies which affect the exchange rate (Madura, 2008).

\section{Hypothesis Development}

EPS information can be used as an illustration of the company's earnings acquisition in the future. The higher earnings per share of a company, the higher the income received by the investor from the investment results so that the high earnings per share of the company impacts the stock price on the market. Research by Shah and Noreen (2016) states that earnings per share have a positive effect on stock price volatility.

$\mathrm{H} 1$ : Earnings per share has an effect on stock price volatility.

Companies that have high growth in asset levels will increase investor confidence so investors will invest their funds in the company. Good or stable growth in asset makes investors have a good view of the company. This causes the stock price to rise quickly and vice versa. Lashgari and Ahmadi (2014) shows that there is a positive influence between growth in assets and stock price volatility.

H2: Growth in asset has an effect on stock price volatility.

Earnings volatility is one of the information used by investors to see the stability of earnings. This unstable income and division cause investors to have less trust in the company. Lack of investor confidence causes a very high change in stock prices both up and down, stock prices become unstable and cause high stock price volatility. Asghar et al. (2011) state that earnings volatility negatively affects stock price volatility. H3: Earnings volatility has an effect on stock price volatility.

The exchange rate is the price of a particular country's currency against another country's currency. When domestic currencies are strengthened investors will be interested in investing domestically. When the domestic currency appreciates investors will be active in trading their shares and there will be a lot of sales resulting in high volatility in stock prices. Research by Adjasi (2009) the exchange rates have a positive effect on stock price volatility.

$\mathrm{H} 4$ : Exchange rates have an effect on stock price volatility.

Interest rates as fees for loaned capital are measured annually. Rising interest rates cause investors to withdraw their shares and move them to savings or deposits. A large number of investors who sell their shares will cause the stock price volatility to be high. Research by Khan (2018) shows that interest rates have an influence on the stock price movements of companies in Pakistan. H5: Interest rates have an effect on stock price volatility.

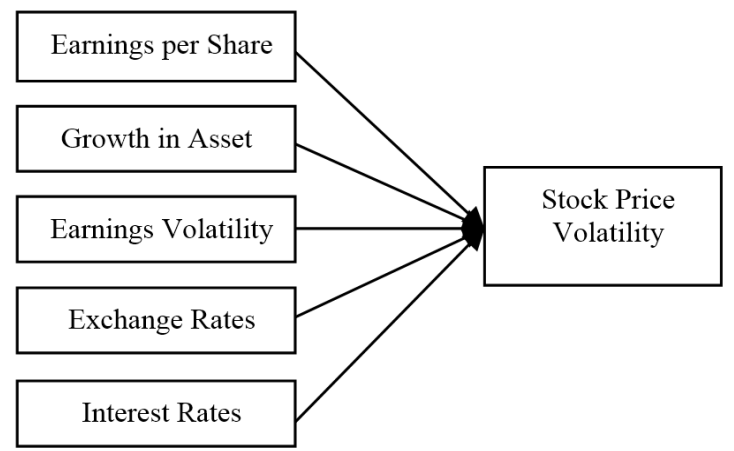

Figure 1. Framework for the Case Study of Indonesia and Malaysia

\section{METHOD}

The type of research used in this study is quantitative research. The data used are secondary data in the form of quarterly financial statements. The objects used are financial sector companies listed on the Indonesia Stock Exchange (IDX) and Malaysia Stock Exchange (MYX) in 2016-2017. The population in this study are companies in the financial sector that have been listed on the Indonesia Stock Exchange (IDX) and the Malaysia Stock Exchange (MYX). The sample was determined using purposive sampling.

This technique was used with the aim of directing data collection to suit the needs and carried out by selecting informants who really mastered the information and existing problems and could be trusted (Oktavilia \& Khoiruddin, 2017). The criteria used are companies in the financial sector whose shares are traded on the Indonesia Stock Exchange (IDX) and Malaysia Stock Exchange (MYX) during 2016-2017 and have a maximum IPO in 2014 and who publish their financial statements in full. 


\section{Stock Price Volatility}

Stock price volatility is a change in the rise and fall of stock prices over a certain period. Stock prices volatility can be calculated by the formula (Shah \& Noreen, 2016):

$$
P V=\sqrt{\left(\frac{H t-L t}{\left(\frac{H t+L t}{2}\right)}\right)^{2}}
$$

Where:

PV : Price Volatility

Ht : Highest Stock Price in $\mathrm{t}$ Period

Lt : Lowest Stock Price t Period

\section{Earnings Per Share}

Earnings Per Share (EPS) is net income per year divided by the number of shares outstanding. EPS can be calculated by the formula (Shah $\&$ Noreen, 2016):

$$
\text { EPS }=\frac{\text { Net Profit }}{\text { Number of Shares }}
$$

\section{Growth in Asset (GA)}

Growth in Asset is a change in total assets in the current year with the previous year. GA can be calculated by the formula

$$
G A=\frac{T A_{t}-T A_{t-1}}{T A_{t-1}}
$$

Where:

GA : Growth in Asset

$\mathrm{TA}_{\mathrm{t}}$ : Total Asset $\mathrm{t}$

$\mathrm{TA}_{\mathrm{t}-1}$ : Total Asset t-1

\section{Earnings Volatility (EV)}

Earnings Volatility is the standard deviation of income before interest and tax compared to total assets. The formula used is (Bradley et al., 1984):

$$
E V=\frac{s t d(E B I T)}{T A}
$$

Where:

EV : Earnings Volatility

EBIT : Earnings Before Interest and Tax

TA : Total Asset

The exchange rate is the price of a country's currency against another country's cur- rency. The exchange rate used in this study is the Rupiah against the US Dollar exchange rate and the Ringgit exchange rate against the US Dollar obtained from the official website of Bank Indonesia (BI) and Bank Negara Malaysia (BNM). The interest rate is a percentage of the cost of a capital loan measured in US dollars. Interest rates are obtained from the official website of Bank Indonesia (BI) and Bank Negara Malaysia (BNM).

The data used in this study is secondary data in the form of quarterly financial statements in 2016-2017. The data was obtained through the official website of the Indonesia Stock Exchange (IDX) and the Malaysia Stock Exchange (MYX) and the official website of each financial sector company as well as the official website of Bank Indonesia and Bank Negara Malaysia. Data analysis method used is descriptive analysis, normality test, multicollinearity test, autocorrelation test, partial test, common effect model, lagrange multiplier test, random effect model, simultaneous test and coefficient of determination using eviews 9. After doing descriptive analysis, the model tested with normality, multicollinearity and autocorrelation. After fulfilling the three tests, it was continued by testing the hypothesis using common effect model regression analysis and random effect model. The lagrange multiplier test is conducted to determine which model is a good common effect model or a random effect model.

\section{RESULT AND DISCUSSION}

\section{Indonesian Sample}

This research is to test the normality of the data by looking at the value of Jarque-Bera (JB). Criteria for normally distributed data are data that has a Jarque-Bera (JB) value with a probability of more than 0.05 . The results of the normality test indicate that the Jarque-Bera value is 2.9074 with a probability value of 0.2336 greater than 0.05 , so it can be concluded that the regression model used is normally distributed.Multicollinearity test is seen from the correlation value between the independent variables which is below 0.9 . The test results show that the correlation between independent variables has a value of less than 0.9 so that it can be concluded that there is no multicollinearity. Autocorrelation test can be known using the Durbin-Watson (DW) test. Criteria for data that does not occur autocorrelation is located between the upper limit (du) and (4-du). The results of the autocorrelation test showed that there was no autocorrelation because the value of Durbin-Watson $(2,0376)$ was located between the value $1.8330(\mathrm{du})$ and $2.1670(4-\mathrm{du})$. 
Table 1. Regression Analysis of Indonesia

\begin{tabular}{lrrrr}
\hline Variabel & t-Statistic & Prob. & t-Table & $\begin{array}{l}\text { Coeffi- } \\
\text { cient }\end{array}$ \\
\hline SQRTEPS & -2.6946 & .0074 & 1.9673 & -.0045 \\
SQRTGA & .0723 & .9424 & 1.9673 & .0042 \\
SQRTEV & -1.4649 & .1439 & 1.9673 & -.0128 \\
EXC & -2.2526 & .0250 & 1.9673 & -.0001 \\
INT & -2.2749 & .0236 & 1.9673 & -5.8548 \\
C & 3.0347 & .0026 & 1.9673 & 1.8609 \\
\hline \hline
\end{tabular}

The results showed that t-statistical earnings per share $(-2.6946)$ with a probability of 0.0074 . It can be concluded that earnings per share have a negative effect on stock price volatility. EPS information can be used as an illustration of the company's earnings acquisition in the future. The higher earnings per share of a company, the higher the income received by the investor from the investment results so that the high earnings per share of the company can have an impact on the stock price on the market. The results of the study differ from research Shah and Noreen (2016) states that earnings per share have a positive effect on stock price volatility.

Based on Table 1 shows that the t-statistic value is -0.0723 with a probability of 0.9424 above the 0.05 significance value. That is, growth in assets does not affect the stock price volatility. The best growth in asset makes investors have a good view of the company. This causes a rapid rise in stock prices; on the contrary, if the growth in the asset is low, investors are less interested in investing so that the stock price will also fall rapidly. However, the results of this study indicate that growth in assets does not affect the stock price volatility. This may be due to other factors that make investors invest in not seeing the growth of company assets. This research is not consistent with Lashgari and Ahmadi (2014) which found that growth in assets had a positive effect on stock price volatility.

The test shows that earnings volatility has a t-statistic of -1.4649 and a probability value of 0.1439 . These results can be concluded that earnings volatility has no effect on stock price volatility. High earnings volatility reflects the rapid rise and fall of company profits. The instability of the profit gained by the company as a signal for investors to sell their shares so that it will affect the rise in stock prices quickly. The results of this study are consistent with Lashgari and Ahmadi (2014) which states that earnings volatility has no effect on stock price volatility. However, different from research Asghar et al. (2011) which found that earnings volatility has a negative influence on stock price volatility. The test results can be seen that the exchange rate t-statistic is -2.2526 with a probability level of 0.0250 .

It can be concluded that the exchange rate has a negative effect on stock price volatility. When the domestic currency strengthens, investors will be interested in investing domestically. A large number of stock trading activities that are buying and selling by investors causes high stock price movements. The results of this study are different from the research conducted by Adjasi (2009) which states that the exchange rate has a positive effect on stock price volatility. The test results show the interest rate has t-statistic (-2.2749) and a probability value of 0.0236 . The results concluded that interest rates have a negative influence on stock price volatility.

Interest rates are one of the macro factors that affect stock price volatility. When interest rates rise many investors sell their shares and switch to savings or deposits. A large number of stock trading caused the volatility of share prices to also be high. However, different from the research of Hamid et al. (2017) found that interest rate has a positive effect on stock price volatility.

The test results show that the F-statistic value is 2.5037 with a probability of 0.0305 (less than 0.05). Based on these results it can be concluded that all independent variables that are used together affect the stock price volatility.

$$
\begin{aligned}
P V= & 1.96-0.01 E P S-0.01 G A-0.02 E V-0.00 E X C \\
& -6.46 I N T+\varepsilon
\end{aligned}
$$

Based on the above equation if earnings per share, growth in assets, earnings volatility, exchange rate and interest rates are considered fixed, there will be an increase in stock price volatility of 1.9573 . If there is an increase in earnings per share and other independent variables are considered fixed, it will be followed by a decrease in the volatility of the stock price 0.0055 . When there is an increase in growth in assets and earnings per share, earnings volatility, exchange rates and interest rates are considered fixed, there is a decrease in the stock price volatility by 0.0126 . If there is an increase in earnings volatility and other independent variables are considered fixed, it will be followed by a decrease in stock price volatility of 0.0170 . If the exchange rate rises by 1 unit and other variables are considered to be fixed, it will be followed by a decrease in the volatility of the stock price of 0.0001 . When there is an increase in interest rates and other variables 
are considered to be unchanged, there will be a decrease in stock price volatility of 6.4579 .

Model and the alternative hypothesis $(\mathrm{Ha})$ Random Effect Model. Based on the results of the Lagrange Multiplier Test conducted, the BreuschPagan (Both) results of 0.0062 below 0.05 so that the null hypothesis $\left(\mathrm{H}_{0}\right)$ is rejected and the alternative hypothesis ( $\mathrm{Ha}$ ) is accepted. That is, a good model is the Random Effect Model.

$$
\begin{aligned}
P V= & 1.86-0.00 E P S+0.00 G A-0.01 E V-0.00 E X C \\
& -5.86 I N T+\varepsilon
\end{aligned}
$$

Based on the above equation, if earnings per share, growth in assets, earnings volatility, exchange rates and interest rates are considered fixed, there will be an increase in stock price volatility of 1.8609 . If there is an increase in earnings per share and other independent variables are considered fixed, it will be followed by a decrease in the volatility of the stock price 0.0045 . When there is an increase in growth in assets and earnings per share, earnings volatility, exchange rates and interest rates are considered fixed, there is a decrease in the stock price volatility as much as 0.0042 . If there is an increase in earnings volatility and other independent variables are considered fixed, it will be followed by a decrease in stock price volatility of 0.0128 . If the exchange rate rises by 1 unit and other variables are considered to be fixed, it will be followed by a decrease in the volatility of the stock price of 0.0001 . When there is an increase in interest rates and other variables are considered unchanged, there is a decrease in stock price volatility of 5.8548 . The test results show that the Adjusted R-squared value is 0.0229 . These results can be concluded that $2 \%$ of stock price volatility variables can be explained by earnings per share, growth in assets, earnings volatility, exchange rates, interest rates. While $98 \%(100 \%-2 \%)$ is explained by other variables not tested in this study.

\section{Malaysian Sample}

Data normality test in this study uses the value of Jarque-Bera (JB). Criteria for normally distributed data are data that has a Jarque-Bera (JB) value with a probability of more than 0.05 . The result of the normality test shows that the Jarque-Bera value is 3.3235 with a probability value of 0.1898 greater than 0.05 , so it can be concluded that the regression model used is normally distributed. Multicollinearity test is seen from the correlation value between the independent variables which is below 0.9 . The test results show that the correlation between independent variables has a value of less than 0.9 so that it can be concluded that there is no multicollinearity. Autocorrelation test can be known using the Durbin-Watson (DW) test. Criteria for data that does not occur autocorrelation is located between the upper limit (du) and (4-du). The results of the autocorrelation test showed that there was no autocorrelation because the value of Durbin-Watson (2.0276) was between the values $1.8129(\mathrm{du})$ and $2.1871(4-d u)$.

Table 2. Regression Analysis of Malaysia

\begin{tabular}{crrrc}
\hline Variabel & t-Statistic & Prob. & t-Tabel & Coefficient \\
\hline EPS & -3.8990 & .0001 & 1.9711 & -.0159 \\
GA & .6956 & .4874 & 1.9711 & .5962 \\
EV & -.5731 & .5672 & 1.9711 & -.0391 \\
EXC & 2.7593 & .0063 & 1.9711 & .7867 \\
INT & -.9050 & .3665 & 1.9711 & -47.8139 \\
C & -1.7791 & .0767 & 1.9711 & -4.3263 \\
\hline \hline
\end{tabular}

The results of the study show that the t-statistical earnings per share (-3.8990) with a probability of 0.0001 . It can be concluded that earnings per share have a negative effect on stock price volatility. EPS information can be used as an illustration of the company's earnings acquisition in the future. The higher earnings per share of a company, the higher the income received by the investor from the investment results so that the high earnings per share of the company can have an impact on the stock price on the market. The results of the study differ from research Adesola and Okwong (2009) states that earnings per share have a positive effect on stock price volatility.

Based on Table 1 shows that the t-statistic value is 0.6956 with a probability of 0.4874 above the significance value of 0.05 . That is, growth in assets does not affect the stock price volatility. The best growth in asset makes investors have a good view of the company. This causes a rapid rise in stock prices; on the contrary, if the growth in the asset is low, investors are less interested in investing so that the stock price will also fall rapidly. However, the results of this study indicate that growth in assets does not affect the stock price volatility. This may be due to other factors that make investors invest in not seeing the growth of company assets. This research is not consistent with Hussainey et al. (2011) which found that growth in assets negatively affects stock price volatility.

The results show that earnings volatility has a t-statistic of -0.5731 and a probability value 
of 0.5672 . These results can be concluded that earnings volatility has no effect on stock price volatility. The higher earnings volatility reflects the rapid rise and fall of company profits. The instability of the profit gained by the company as a signal for investors to sell their shares so that it will affect the rise in stock prices quickly. The results of this study are consistent with Lashgari and Ahmadi (2014) which states that earnings volatility has no effect on stock price volatility. However, different from research Rowena and Hendra (2017) which found that earnings volatility has an influence on stock price volatility.

The results can be seen that the exchange rate t-statistic is 2.7593 with a probability level of 0.0063 . It can be concluded that the exchange rate has a positive effect on stock price volatility. When the domestic currency strengthens, investors will be interested in investing domestically. A large number of stock trading activities that are buying and selling by investors causes high stock price movements. The results of this study are different from the research conducted by Selpiana and Badjra (2018) which states that the exchange rate has a positive effect on stock price volatility.

The results show the interest rate has t-statistic $(-0.9050)$ and a probability value of 0.3665 . The results concluded that interest rates have no effect on stock price volatility. Interest rates are one of the macro factors that affect stock price volatility. When interest rates rise many investors sell their shares and switch to savings or deposits. A large number of stock trading caused the volatility of share prices to also be high. This research is consistent with Azura et al. (2018) which states that interest rates do not affect the stock price volatility. However, different from research Hamid et al. (2017) who found that interest rates have a positive effect on stock price volatility. The results show that the F-statistic value is 5.9634 with a probability of 0.0000 (less than 0.05 ). Based on these results it can be concluded that all independent variables that are used together affect the stock price volatility.

$$
\begin{aligned}
P V= & 4.13-0.01 E P S+0.82 G A-0.09 E V-0.75 E X C \\
& -49.98 I N T+\varepsilon
\end{aligned}
$$

Based on the above model, if earnings per share, growth in assets, earnings volatility, exchange rates and interest rates are considered fixed, there will be a decrease in stock price volatility of 4,1293 . If there is an increase in earnings per share and other independent variables are considered fixed, it will be followed by a decrease in the volatility of the stock price 0.0131 . When there is an increase in growth in assets and earnings per share, earnings volatility, the exchange rate and interest rates are considered fixed, there is an increase in the volatility of the stock price by 0.8151 . If there is an increase in earnings volatility and other independent variables are considered fixed, it will be followed by a decrease in stock price volatility of 0.0930 . If the exchange rate rises by 1 unit and other variables are considered to be fixed, it will be followed by an increase in stock price volatility of 0.7513 . When there is an increase in interest rates and other variables are considered to be unchanged, there will be a decline in the volatility of the stock price of 49.9751 .

The hypothesis proposed is the null hypothesis $\left(\mathrm{H}_{0}\right)$ Common Effect Model and the alternative hypothesis (Ha) Random Effect Model. Based on the results of the Lagrange Multiplier Test conducted, the Breusch-Pagan (Both) results of 0.0003 below 0.05 so that the null hypothesis $\left(\mathrm{H}_{0}\right)$ is rejected and the alternative hypothesis (Ha) is accepted. That is, a good model is the Random Effect Model.

$$
\begin{aligned}
P V= & 4.33-0.02 E P S+0.60 G A-0.04 E V-0.79 E X C \\
& -47.8 I N T+\varepsilon
\end{aligned}
$$

Based on the above equation, if earnings per share, growth in assets, earnings volatility, exchange rates and interest rates are considered fixed, there will be a decrease in stock price volatility of 4.3263. If there is an increase in earnings per share and other independent variables are considered fixed, it will be followed by a decrease in stock price volatility of 0.0159 . When there is an increase in growth in assets and earnings per share, earnings volatility, the exchange rate and interest rates are considered fixed, there will be an increase in the volatility of share prices as much as 0.5962 . If there is an increase in earnings volatility and other independent variables are considered fixed, it will be followed by a decrease in stock price volatility of 0.0391 . If the exchange rate rises by 1 unit and other variables are considered to be fixed, it will be followed by an increase in the volatility of the share price of 0.7867 . When there is an increase in interest rates and other variables are considered not to change, there is a decrease in stock price volatility of 47,8139 . Test results show that the adjusted R-squared value is 0.1043 .

These results can be concluded that $10.43 \%$ of stock price volatility variables can be explained by earnings per share, growth in assets, earnings 
volatility, exchange rates, interest rates. While $89.57 \%(100 \%-10.43 \%)$ is explained by other variables not tested in this study.

\section{CONCLUSION AND RECOMMENDA- TION}

The conclusions obtained from the previous discussion are earnings per share variables in the State of Indonesia and Malaysia, which negatively affect stock price volatility. The higher earnings per share, the lower the stock price volatility. Variable growth in assets in Indonesia and Malaysia do not affect the stock price volatility. This is possible because investors tend not to pay attention to growth in an asset in investing. Earnings volatility variables in Indonesia and Malaysia do not affect the stock price volatility. This may be because earnings volatility as a signal does not provide good information for investors.

Exchange rates variable in Indonesia have a negative effect on stock price volatility. The higher the exchange rate, the lower the stock price volatility. Meanwhile, the exchange rate in Malaysia has a positive effect. The higher the exchange rate, the higher the stock price volatility. Variable interest rates in Indonesia have a negative effect. The higher the interest rate in Indonesia, the lower the stock price volatility. Meanwhile, interest rates in the Malaysian State have no effect on stock price volatility. This is possible because investors do not fully pay attention to interest rates but other macro factors, such as exchange rates, inflation, or market value.

\section{REFERENCES}

Adesola, W. A., \& Okwong, A. E. (2009). An Empirical Study of Dividend Policy of Quoted Companies in Nigeria. Global Journal of Social Sciences, 8(1), 85 .

Adhita, L. D., \& Agustin, S. (2013). Pengaruh Fundamental Inflasi dan Suku Bunga terhadap Perubahan Harga Saham Perusahaan LQ45. Jurnal Ilmu dan Riset Manajemen, 2(3), 1-25.

Adjasi, C. K. (2009). Macroeconomic Uncertainty and Conditional Stock-Price Volatility in Frontier African Markets: Evidence from Ghana. The Journal of Risk Finance, 10(4), 333-349.

Ardhi, H. S., Hasan, H. A., Efni, Y., Rokhmawati, A., \& Gusnardi, G. (2017). Pengaruh Variabel Makro Ekonomi dan Kinerja Keuangan terhadap Return Saham pada Industri Otomotif di Bursa Efek Indonesia (Studi pada Perusahaan Sektor Otomotif di Bursa Efek Indonesia). KURS (Jurnal Akuntansi, Kewirausahaan dan Bisnis), 2(1), 111-118.

Asghar, M., Shah, S. Z. A., Hamid, K., \& Suleman, M.
T. (2011). Impact of Dividend Policy on Stock Price Risk: Empirical Evidence from Equity Market of Pakistan. Far East Journal of Psychology and Business, 4(1), 45-52.

Asih, N. W. S., \& Akbar, M. (2017). Analisis Pengaruh Inflasi, Suku Bunga, Nilai Tukar (Kurs) dan Pertumbuhan Produk Domestik Bruto (PDB) terhadap Indeks Harga Saham Gabungan (IHSG) Studi Kasus pada Perusahaan Properti yang Terdaftar di Bursa Efek Indonesia. Jurnal Manajemen dan Akuntansi, 17(1), 43-52.

Atmaja, L. S. (2008). Teori dan Praktik Manajemen Keuangan. Yogyakarta: Andi.

Azura, S. N., Sofia, M., \& Nurhasanah. (2018). Faktor-Faktor yang Mempengaruhi Volatilitas Harga Saham pada Perusahaan Manufaktur yang Tercatat di Bursa Efek Indonesia Tahun 2012-2016.

Bradley, M., Jarrell, G. A., \& Kim, E. H. (1984). On the Existence of an Optimal Capital Structure: Theory and Evidence. The Journal of Finance, 39(3), 857-878.

Brealey, R. A., Myers, S. C., \& Marcus, A. (2015). Fundamentals of Corporate Finance (Eight). New York: McGraw Hill.

Cahyaningdyah, D., \& Ressany, Y. D. (2012). Pengaruh Kebijakan Manajemen Keuangan Terhadap Nilai Perusahaan. Jurnal Dinamika Manajemen, 3(1), 20-28.

Hamid, K., Usman Khurram, M., \& Ghaffar, W. (2017). Juxtaposition of Micro and Macro Dynamics of Dividend Policy on Stock Price Volatility in Financial Sector of Pakistan: (Comparative Analysis through Common, Fixed, Random and Gmm Effect). Journal of Accounting, Finance and Auditing Studies, 3(1), 64-79.

Hartini, W. (2012). Pengaruh Financial Ratio terhadap Pertumbuhan Laba dengan Pengungkapan Corporate Social Responsibility sebagai Variabel Pemoderasi. Management Analysis Journal, 1(2), 1-7.

Hussainey, K., Oscar Mgbame, C., \& Chijoke-Mgbame, A. M. (2011). Dividend Policy and Share Price Volatility: UK evidence. The Journal of risk finance, 12(1), 57-68.

Ilaboya, O. J., \& Aggreh, M. (2013). Dividend Policy and Share Price Volatility. Journal of Asian Development Studies, 2(2), 109-122.

Indriani, A., \& Widyarti, E. T. (2013). Penentu-Penentu Struktur Modal Perusahaan yang Sahamnya Masuk Jakarta Islamic Index. Jurnal Dinamika Manajemen, 4(1), 59-68.

Khan, M. A. (2018). Assessing the Role of Macroeconomic Variables on Stock Price Volatility: a Case of Pakistan Stock Exchange. Pakistan Business Review, 19(4), 928-943.

Khoiruddin, M., \& Faizati, E. R. (2014). Reaksi Pasar terhadap Dividend Announcement Perusahaan yang Sahamnya Masuk Daftar Efek Syariah. Jurnal Dinamika Manajemen, 5(2), 209-219.

Lashgari, Z., \& Ahmadi, M. (2014). The Impact of Dividend Policy on Stock Price Volatility in the 
Tehran Stock Exchange. Kuwait Chapter of the Arabian Journal of Business and Management Review, 3(10), 273-283.

Lestari, E., \& Sulistyawati, A. I. (2017). Kebijakan Deviden pada Indeks Saham LQ45 di Bursa Efek Indonesia. Jurnal Akuntansi Indonesia, 6(2), 113-130.

Listriono, K., \& Nuraina, E. (2015). Peranan Inflasi, BI Rate, Kurs Dollar (USD/IDR) dalam Mempengaruhi Indeks Harga Saham Gabungan (IHSG). Jurnal Dinamika Manajemen, 6(1), 7383.

Madura, J. (2008). International Financial Management (Ninth). USA: Thomson Higher Education.

Miller, M. H., \& Modigliani, F. (1961). Dividend Policy, Growth and the Valuation of Shares. The Journal of Business, 34(4), 411-433.

Nazir, M. S., Abdullah, \& Nawaz, M. M. (2012). How Dividend Policy Affects Volatility of Stock Prices of Financial Sector Firms of Pakistan. American Journal of Scientific Research, 61(61), 132-139.

Nazir, M. S., Nawaz, M. M., Anwar, W., \& Ahmed, F. (2010). Determinants of Stock Price Volatility in Karachi Stock Exchange: the Mediating Role of Corporate Dividend Policy. International Research Journal of Finance and Economics, 55(55), 100-107.

Nofiatin, I. (2013). Hubungan Inflasi, Suku Bunga, Produk Domestik Bruto, Nilai Tukar, Jumlah Uang Beredar dan Indeks Harga Saham Gabungan (IHSG) Periode 2005-2011. Jurnal Aplikasi Manajemen, 11(2), 215-222.

Oktavilia, S., \& Khoiruddin, M. (2017). Mappings Industry as the Strategy for Enhancing Competitiveness of Industry in Semarang Regency. Advanced Science Letters, 23(8), 7131-7134.

Prasetyo, D. A., \& Darmawan, A. (2017). Pengaruh Risiko Inflasi, Risiko Suku Bunga, Risiko Nilai Tukar dan Leverage terhadap Profitabilitas (Studi pada Perusahaan Sub Sektor Makanan dan Minuman yang Terdaftar di Bursa Efek Indonesia Tahun 2012-2016). Jurnal Administrasi Bisnis, 50(3), 48-56.

Prasetyo, T. (2013). Dividen, Hutang dan Kepemilikan Institusional di Pasar Modal Indonesia: Pengujian Teori Keagenan. Jurnal Dinamika Manajemen, 4(1), 10-22.

Puspida, S., \& Budiyanto. (2013). Pengaruh Risiko Bisnis dan Pertumbuhan Aktiva terhadap Struktur Modal pada PT. Pembangkitan Jawa Bali. Jurnal Ilmu dan Riset Manajemen, 2(2), 1-15.

Ramadan, I. Z. (2013). Dividend Policy and Price Volatility. Empirical Evidence from Jordan. International Journal of Academic Research in Accounting, Finance and Management Sciences, 3(2), 15-22.

Ramdhani, R. (2012). Pengaruh Dividend Yield dan Earning Volatility terhadap Volatiltas Harga Saham di Bursa Efek Jakarta, 3(2), 665-672.

Rowena, J., \& Hendra, H. (2017). Earnings Volatility, Kebijakan Dividen dan Pertumbuhan Asset
Berpengaruh terhadap Volatilitas Harga Saham pada Perusahaan Manufaktur di BEI Periode 2013-2015. Jurnal Administrasi Kantor Bina Insani, 5(2), 231-242.

Safitri, A. L. (2013). Pengaruh Earning per Share, Price Earning Ratio, Return on Asset, Debt to Equity Ratio dan Market Value Added terhadap Harga Saham dalam Kelompok Jakarta Islamic Index. Management Analysis Journal, 2(2), 1-8.

Sari, E. L., \& Wijayanto, A. (2015). Pengaruh Keputusan Investasi, Pendanaan dan Dividen terhadap Nilai Perusahaan dengan Risiko sebagai Variabel Mediasi. Management Analysis Journal, 4(4), 281-291.

Sari, O. T. (2013). Pengaruh Keputusan Investasi, Keputusan Pendanaan dan Kebijakan Dividen terhadap Nilai Perusahaan. Management Analysis Journal, 2(2), 1-7.

Selpiana, K. R., \& Badjra, I. B. (2018). Pengaruh Kebijakan Dividen, Nilai Tukar, Leverage dan Firm Size terhadap Volatilitas Harga Saham. E-Jurnal Manajemen Unud, 7(3), 168-1712.

Setiawan, A. P., \& Wijayanto, A. (2017). Estimasi Volatilitas Saham dengan Metode Momentum (the Methods of Moments) dan Estimasi Kemungkinan Maksimum (Maximum Likelihood Estimation). Management Analysis Journal, 6(2), 1-9.

Shah, S. A., \& Noreen, U. (2016). Stock Price Volatility and Role of Dividend Policy: Empirical Evidence from Pakistan. International Journal of Economics and Financial Issues, 6(2), 461-472.

Sutrisno, B. (2017). Hubungan Volatilitas dan Volume Perdagangan di Bursa Efek Indonesia. Esensi: Jurnal Bisnis dan Manajemen, 7(1), 15-26.

Tandelilin, E. (2010). Portofolio dan Investasi Teori dan Aplikasi. Yogyakarta: Kanisius.

Tastaftian, M., \& Khoiruddin, M. (2015). Analisis Pengaruh Pengumuman Dividen Tunai terhadap Abnormal Return dan Variabilitas Tingkat Keuntungan Saham. Management Analysis Journal, 4(4), 333-340.

Wijayanti, R., \& Diyanti, V. (2017). Pengaruh Volatilitas Laba, Perataan Laba dan Corporate Governance terhadap Kualitas Laba Bank Syariah dan Konvensional. Jurnal Akuntansi dan Investasi, 18(1), 66-79.

Yanto, H., Yulianto, A., Sebayang, L. K. B., \& Mulyaga, F. (2017). Improving the Compliance with Accounting Standards Without Public Accountability (SAK ETAP) by Developing Organizational Culture: a Case of Indonesian SMEs. The Journal of Applied Business Research, 33(5), 929-940.

Yendrawati, R., \& Pratiwi, R. S. I. (2015). Relevansi Nilai Informasi Laba dan Arus Kas terhadap Harga Saham. Jurnal Dinamika Manajemen, 5(2), 161-170.

Yulianto, A., Suseno, D. A., \& Widiyanto. (2015). Testing Pecking Order Theory and Trade-Off Theory Models in Public Companies in Indonesia. Handbook on Business Strategy and Social Sciences, 3(4), 13-18. 